\title{
Symbiotic Effectiveness of Rhizobia Strains Isolated from Nigerian Savanna
}

\author{
Saheed Tunde Bolarinwa*, Anthony Ozoemenam Uzoma \\ Department of Soil Science and Land Management, Federal University of Technology \\ P.M.B 65, Minna, Niger State.
}

*Carresponding Authar email:

saheedtee@gmail.com

Article History

Received: 21 July 2018

Accepted: 13 September 2018

Published: 01 October 2018

Student(s)

- $\quad$ Saheed Tunde Bolarinwa

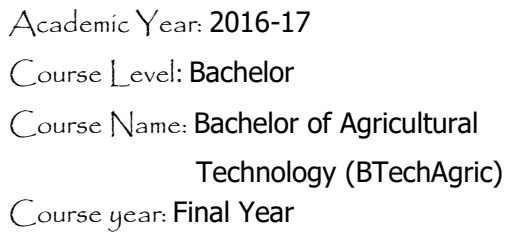

Mentar(s)

- Anthony Ozoemenam Uzoma

\section{ABSTRACT}

Laboratory and screenhouse experiment were conducted to assess the symbiotic effectiveness (SE) of rhizobia isolated from southern Guinea savanna, northern Guinea savanna and Sudan savanna of Nigeria and response of promiscuous soybean varieties, TGx1448-2E, TGx1835-10E and TGx1955-10E to inoculation with ten indigenous rhizobia isolates. The soybean varieties were grown on sterilized sand at the screenhouse of the Department of Soil Science and Land Management, Federal University of Technology Minna and watered using Sandsman's nutrient solution. The treatments were un-inoculated control, mineral nitrogen (urea) and ten rhizobia isolates arranged on a Completely Randomized Design (CRD) and replicated three times. The rhizobia isolates were $\mathrm{Sg} 4, \mathrm{Sg} 6-3$, Gw5, Gw3-2, Bg3, Bg1-4, Sk2-3, Am2, Am6-3 and Kr5-5 isolated from Sabon-gida, Gwada, Birnin-gwari, Shika, Amawa and Karaye sites of Nigerian savanna. The results obtained were subjected to Analysis of Variance using statistical analysis system (SAS 2008) computer software. The treatments mean was separated using Least Significant Different (LSD) at 5\% probability. Nodulation and biomass yield of the varieties were assessed at six weeks after planting. Nodules were only produced in inoculated plants, SE was calculated. The result obtained showed that nodule dry weight, SE and shoot dry weight were significantly affected by the interaction between inoculation and promiscuous soybean varieties. Generally, inoculated plants gave higher shoot biomass gain than the un-inoculated control but lower than those treated with urea. The difference between those inoculated and those treated with urea was associated to environmental specificities and higher temperature during the period of the experiment. The SE was highest in northern Guinea savanna isolate reaching 67\% and lowest in southern Guinea savanna isolate Sg6-3 recorded $53 \%$. The result showed an SE of less than $100 \%$ in all the isolates which implies that the indigenous rhizobia isolates were not superior to the mineral nitrogen.

Keyword: Rhizobia, inoculation, symbiotic effectiveness, soybean varieties. 


\section{Introduction}

Rhizobia are symbiotic bacteria associating with legumes that fix atmospheric nitrogen through Biological Nitrogen Fixation (BNF) process. The rhizobia genera are able to provide the plants with macronutrients. Rhizobia-legume symbiosis starts with complex molecular interaction of synthesized Nod factors by the bacterium and released flavonoids by legume roots, so that both associating partners can recognize each other and initiate nodulation [1]. Rhizobia enter root cortical cells due to the nod factors that change the root morphology and become encased by a plant-derived membrane, differentiate into bacteroids, and fix nitrogen [2]. [3] also observed that even in the absence of a legume host plant, rhizobia live freely in the soil, and their community can persist for several years. As organisms that live freely, rhizobia derive their nourishment from decaying or dead organic matter and thus contribute to organic matter decomposition and nutrient cycling. Nitrogen fixation may be lost because the nodulation codes provided by the genetic material generally exist in small packets of genetic information, called plasmids, floating like tiny "symbiosis islands" within the bacterial cell [4]. The study of [5] demonstrated that rhizobia have diverse lifestyle and are heterotrophic soil bacteria with some lineages having the ability to nodulate and fix atmospheric nitrogen on legume roots. The legume-rhizobia relationship is vital for agriculture, as it may influence greenhouse gas emission mitigation, lowering farmer's cost, sustainability of land and soil quality. Importance of symbiosis is majorly attributed to the rehabilitation of infertile, environmentally stressed soils and decrease in the use of costly nitrogen-based fertilizers. With the need to reduce carbon emissions and increase global demand for food production, the dependence on BNF as a substitute to nitrogen fertilizers is predicted to rise [6]. Phylogenetically, rhizobia that are capable of fixing atmospheric nitrogen in symbiosis with legumes are categorized under the class of alpha-proteobacteria and beta-proteobacteria with majority of the species belonging to class alpha-proteobacteria, order Rhizobiales, amongst which include Azorhizobium, Rhizobium, Bradyrhizobium, Mesorhizobium and Sinorhizobium. One impediment to the broader use of rhizobia in agriculture is the production of compatible inoculants. Symbiotic relationships has facilitated rapid adaptation of species to differing new niches [7], nutrient cycling transformation [8] and driven diversification of organisms [9]-[10]. Organisms mostly rely on symbiotic partnerships for some form of protection, metabolism, or energy [11]-[12]. These partnerships can be achieved if the associating partners are aligned tightly or partners have developed mechanisms to coordinate and control interactions [13]-[15].

Nitrogen is found to be the most limiting nutrient element required for plant growth and development [16] and as such, average soybean yield on marginal soils of Nigeria is below 1 ton ha-1 ${ }^{-1}$ [1] whereas a yield of about 2.5 - 3.0 tons ha $^{-1}$ is possible [18]. The abuse of inorganic nitrogen fertilizers lead to severe pollution problems and it requires high amounts of non-renewable fossil energy for production and thus releases greenhouse gases [19]. Therefore, the association between rhizobia and legumes for BNF is the best approach because it utilizes energy produced during photosynthesis and is globally friendly [20]. Although rhizobia live freely in the soils but native strains are not essentially effective Nitrogen fixers, and the elite rhizobia strains overtime lose significant levels of nitrogen fixation [21] as there are environmental specificities, substantial host and strain that limit the process of nitrogen fixation [22]. Improved legume production by inoculating the soils with the compatible and effective bacteria for effective BNF is not feasible and where the native bacteria population is low, inoculation is required [23]. Hence the need to screen native strains that are symbiotically effective with TGx varieties that are promiscuous.

Atmospheric nitrogen is being metabolized and converted into nitrogen compounds that the plant can take up by rhizobia; this takes place on plant roots structure called nodules. During this process, carbon substrates obtained from photosynthesis is utilize by rhizobia, and thereby enriching the crop with nitrogen represents a significant cost to both farmer and the environment. Biological nitrogen fixation (BNF) is less costly and more sustainable but most African soils have characteristic low levels of BNF activities and usually do not enhance high yields of soybean without external application of soybean rhizhobia or addition of chemical nitrogen fertilizers [23]. The BNF resulting from rhizobia associating with legumes can benefit 
Bolarinwa et al., Adv. J. Grad. Res.; Vol. 5, Issue 1, pp: 24-32, January 2019

both the host crop and subsequent crops [24] and as such, up to $200 \mathrm{~kg} \mathrm{~N} / \mathrm{ha}$ can be fixed by soybean plants associating with rhizobia per year thereby the abuse of nitrogen fertilizers which are expensive and environmentally harmful is reduced [25]. Furthermore, with economically important non-legume crops such as wheat or rice, rhizobia may also act as non-symbiotic plant growth-promoting bacteria (PGPB) [26]. For all these reasons, the association between legume and rhizobia has been widely studied as a beneficial association for sustainable agriculture and as a model of mutualistic associations.

The aim of this research is to investigate the effectiveness of ten rhizobia isolates obtained from Nigerian savanna. The objectives access growth and nodulation characteristics of three (3) promiscuous soybean varieties, investigate response to inoculation of these varieties with the rhizobium isolates and investigate symbiotic effectiveness of these rhizobia isolates associating with soybean varieties.

\section{Materials and Methods}

\subsection{Study Area}

The experiment was carried out at the greenhouse of Federal University of Technology Minna at latitude of $9^{0} 32^{\prime} 0.5^{\prime \prime} \mathrm{N}$ and longitude $6^{0} 27^{\prime} 8.6^{\prime \prime} \mathrm{E}$. Minna is located on latitude $9^{0} 36^{\prime} 54.86^{\prime \prime} \mathrm{N}$ and longitude $6^{0}$ 32' 51.94" E, it is found in the Southern Guinea Savanna vegetation zone of Nigeria. The mean annual rainfall of Minna is about $1300 \mathrm{~mm}$, has a sub-humid climate and a distinct dry season from November to March which is about 5 months duration [27]. This region is characterized by double rainfall maxima with fluctuation in amount of rainfall received per year. The rainy season starts at most time in April and persist till October [27].

\subsection{Soil Description and Vegetation}

The soils of the guinea savanna and Sudan savanna zone as described by Food and Agricultural Organization is found on extensive crystalline basement complex which are intrusive igneous rock that have been in existence since the Precambrian time. They are made up of ferruginous tropical soil which is derived from intensive weathering and granitization of the basement which are mostly magmatites, gneiss, granite and schist. The vegetation in the guinea savannah zone consists typically of tall grasses (pennisetum, andropogon, panicum, chloris) and short trees (mangoes, locust bean trees, shea butter trees) comparatively with the Sudan savanna that consists of fewer trees and shorter grasses such as Acacia, Tamarind trees. The region which consists of mixed grassland and forest provide habitation for a range of species from large mammals to more localized small species.

\subsection{Sand Washing, Autoclaving and Pot Filling}

The sand was collected from a river side, washed for numerous times to remove other soil particles present and available nutrients which are soluble. The sand was however sterilized using an autoclave machine at a temperature of $121^{\circ} \mathrm{C}$ for 20 minutes; the purpose of this was to kill all microbes present in the sand particle and thereby making it sterile. The poly pots were filled with $2.5 \mathrm{~kg}$ of the sterilized sand which served as the growth medium.

\subsection{Sandman Nutrient Preparation and Basal Application}

The nutrient solution was prepared according to Sandman's procedure as follows; Stock solution of iron was prepared by dissolving $5 \mathrm{~g}$ each of $\mathrm{FeS}_{4} .7 \mathrm{H}_{2} \mathrm{O}$ and Citric acid in $1000 \mathrm{mls}$ of distilled water. Thereafter, micronutrient solution was prepared by dissolving $\mathrm{CuSO}_{4} \cdot 5 \mathrm{H}_{2} \mathrm{O}(0.157 \mathrm{~g}), \mathrm{ZnSO}_{4} \cdot 7 \mathrm{H}_{2} \mathrm{O}(0.44 \mathrm{~g})$, $\mathrm{MnSO}_{4} \cdot 7 \mathrm{H}_{2} \mathrm{O}(3.076 \mathrm{~g}),\left(\mathrm{NH}_{4}\right)_{6} \mathrm{Mo}_{7} 0_{24} \cdot 4 \mathrm{H}_{2} \mathrm{O}(0.02 \mathrm{~g})$ and $\mathrm{H}_{3} \mathrm{BO}_{3}(2.26 \mathrm{~g})$ in $1000 \mathrm{mls}$ of dissolved water. The calcium solution in which $200 \mathrm{ml}$ was added to the sand before sowing was obtained by dissolving $\mathrm{KNO}_{3}$ $(0.2 \mathrm{~g})$ and $\mathrm{CaSO}_{4}(2.5 \mathrm{~g})$ in $100 \mathrm{mls}$ of distilled water. The watering medium was therefore achieved by dissolving $\mathrm{KCl}(0.149 \mathrm{~g}), \mathrm{MgSO}_{4} \cdot 7 \mathrm{H}_{2} \mathrm{O}(0.493 \mathrm{~g}), \mathrm{K}_{2} \mathrm{HPO}_{4}(0.348 \mathrm{~g}), 5 \mathrm{ml}$ of iron solution and $5 \mathrm{ml}$ of micronutrient solution into $1000 \mathrm{mls}$ of distilled water. 


\subsection{Treatments and Experimental Design}

The potted experiment was laid out on a Completely Randomized Design (CRD). The factors were soybean varieties and rhizobia isolate. The treatments were three (3) soybean varieties (TGx1835-10E, TGx14482E and TGx1955-10E) inoculated with ten rhizobia isolates (Sg4, Sg6-3, Gw5, Gw3-2, Bg3, Bg1-4, Sk2-3, Am2, Am2-3 and Kr5-5), a plus-nitrogen $\mathrm{N}+$ and a control (minus-nitrogen $\mathrm{N}-$ ). All treatments were replicated three times.

\subsection{Planting and Crop Management}

Soybean varieties obtained from Institute for Agricultural Research (IAR) Samaru was surface sterilized by washing in $5 \%$ hypochlorite solution for few moments to remove the trapped air and waxy material. The seeds were then rinsed in five changes of distilled sterile water. The filled poly pots were watered with Sandman solution to field capacity prior to planting of the seeds. Four well-spaced holes were made in the poly pots filled with sterilized sand after which one seed was placed in each hole and properly covered. Watering was done frequently with the prepared Sandman solution. At one week after sowing, the plants were thinned to two seedlings per pot.

\subsection{Yeast Mannitol Broth Preparation and Inoculation}

The inoculants were native rhizobia strains isolated from soils obtained from Sabon-gida and Gwada in Niger state (Sg4, Sg6-3, Gw5 and Gw3-2), Birnin gwari and Shika in Kaduna state (Bg3, Bg1-4 and Sk2-3) and Amawa and Karaye in Kano state (Am2, Am6-3 and Kr5-5). These rhizobia isolates represent groups under high, medium and low symbiotic effectiveness. Prior to inoculation, each of these isolates were cultured on Yeast Mannitol Broth (YMB) in slant bottles. Note that YMB contains: $5 \mathrm{~g}$ Mannitol, $0.25 \mathrm{~g}$ $\mathrm{K}_{2} \mathrm{HPO}_{4}, 0.1 \mathrm{~g} \mathrm{MgSO}_{4} .7 \mathrm{H}_{2} \mathrm{O}, 0.05 \mathrm{~g} \mathrm{Nacl}, 0.5 \mathrm{~g} \mathrm{CaCO}_{3}, 0.5 \mathrm{~g}$ Yeast Extract in $500 \mathrm{ml}$ of distilled water. The culturing was done for 5 days at $25-28{ }^{\circ} \mathrm{C}$ on a rotary shaker at $100 \mathrm{rev} / \mathrm{min}$. Thereafter, cultures in YMB were dispensed at the base of the plants using a fresh syringe for each isolate at the rate of $5 \mathrm{ml}$ per plant.

\subsection{Harvesting and Tissue Sampling for Symbiotic Effectiveness}

The plants were harvested at 6 weeks after sowing. Sand was removed carefully, and the nodule number was determined. The plant shoots and nodule weight on dry weight basis was then obtained after drying for 3 days in an oven at a temperature of $65^{\circ} \mathrm{C}$. Percentage symbiotic effectiveness (\%SE) was scored on the basis of increased shoot dry weight and accumulation of the inoculated plants in comparison with the un-inoculated controls as follows:

Percentage symbiotic effectiveness $(\%$ SE $)=\frac{d-n}{d+n} \times 100$.

Where $d-n$ is the dry weight of plants without $\mathrm{N}$ supply while $\mathrm{d}+\mathrm{n}$ is the dry weight of plants with $\mathrm{N}$ supply. Nodules were also collected and stored on a silica gel in refrigerator to be recovered later for further rhizobial isolation and purification in the laboratory.

\subsection{Statistical Analysis}

All the obtained data from the experiment were subjected to analysis of variance (ANOVA) at $5 \%$ level of significance using the SAS window version 9.1 [28]. The treatments mean was separated by using least significant difference (LSD).

\section{Results}

\subsection{Main Effect of N-sources on Shoot Biomass, Nodulation and Symbiotic Effectiveness on Soybean Varieties}

The main effect of rhizobia inoculation on nodulation and shoot dry weight is shown in Table 1. Nodulation of promiscuous soybean varieties with indigenous rhizobia isolates across all treatments were observed in the experiment. The control plants produced no nodules. The number of nodules formed by the isolates differed significantly with isolate Bg1-4 producing the highest number that was not statistically different 
Bolarinwa et al., Adv. J. Grad. Res.; Vol. 5, Issue 1, pp: 24-32, January 2019

from the number of nodules produced by isolates Gw5, Sk2-3 and $\mathrm{Kr} 5-5$. Isolates Sg4, Gw3-2, Bg3, Am63 and Sg6-3 recorded nodule numbers that were not statistically different $(\mathrm{P}<0.05)$ while isolate $\mathrm{Am} 2$ produced the least. The highest nodule weight was observed in plants inoculated with isolate Bg1-4 while Sg4 and Gw5 produced nodule weights that were not significantly different from those of plants inoculated with isolate Bg1-4. Nodule weight of plants inoculated with isolates Sg6-3, Am6-3, Am2, Sk2-3 and Gw32 were not significantly different from one another but they were different from the nodule weight of $\mathrm{Bg} 3$ inoculated plants. The interaction effect of inoculation and variety was highly significant $(\mathrm{P}<0.01)$ on shoot biomass but only significant $(\mathrm{P}<0.05)$ on nodule dry weight and symbiotic effectiveness which was not significant on nodule number.

Table 1: Main Effect of $N$-sources on Shoot biomass, Nodulation and Symbiotic Effectiveness on Soybean Varieties

\begin{tabular}{|c|c|c|c|c|}
\hline Treatment & $\begin{array}{l}\text { Shoot dry weight } \\
\left(\text { g plant }^{-1}\right)\end{array}$ & Nodule number & $\begin{array}{l}\text { Nodule dry weight } \\
\left(\mathrm{g} \mathrm{plant}^{-1}\right)\end{array}$ & $\begin{array}{l}\text { Symbiotic } \\
\text { effectiveness (\%) }\end{array}$ \\
\hline \multicolumn{5}{|l|}{ N-Sources } \\
\hline Control & $1.75^{\mathrm{e}}$ & $0.00^{\mathrm{d}}$ & $0.00^{\mathrm{e}}$ & $0^{\mathrm{d}}$ \\
\hline Urea & $3.61^{\mathrm{a}}$ & $0.00^{\mathrm{d}}$ & $0.00^{\mathrm{e}}$ & $\overline{0^{\mathrm{d}}}$ \\
\hline $\mathrm{Sg} 4$ & $1.96^{\mathrm{de}}$ & $1.11^{\mathrm{bc}}$ & $0.038^{\mathrm{ab}}$ & $55^{\mathrm{c}}$ \\
\hline Sg6-3 & $1.87^{\mathrm{de}}$ & $1.11^{\mathrm{bc}}$ & $0.012^{\text {cde }}$ & $53^{c}$ \\
\hline Gw5 & $2.07^{\mathrm{cd}}$ & $1.44^{\mathrm{ab}}$ & $0.029^{\mathrm{abc}}$ & $59^{\mathrm{bc}}$ \\
\hline Gw3-2 & $2.00^{\mathrm{cd}}$ & $1.00^{\mathrm{bc}}$ & $0.016^{\text {cde }}$ & $55^{\mathrm{c}}$ \\
\hline $\mathrm{Bg} 3$ & $2.03^{\mathrm{cd}}$ & $1.11^{\mathrm{bc}}$ & $0.019^{\text {cd }}$ & $58^{\mathrm{bc}}$ \\
\hline Bg1-4 & $2.35^{\mathrm{b}}$ & $2.22^{\mathrm{a}}$ & $0.041^{\mathrm{a}}$ & $67^{\mathrm{a}}$ \\
\hline Sk2-3 & $2.21^{\mathrm{bc}}$ & $1.44^{\mathrm{ab}}$ & $0.016^{\text {cde }}$ & $63^{\mathrm{ab}}$ \\
\hline Am2 & $1.97^{\mathrm{de}}$ & $0.44^{\text {cd }}$ & $0.005^{\mathrm{de}}$ & $56^{\mathrm{c}}$ \\
\hline Am6-3 & $1.91^{\mathrm{de}}$ & $1.22^{\mathrm{bc}}$ & $0.013^{\text {cde }}$ & $54^{c}$ \\
\hline Kr5-5 & $1.94^{\mathrm{de}}$ & $1.78^{\mathrm{ab}}$ & $0.022^{\mathrm{bcd}}$ & $55^{\mathrm{c}}$ \\
\hline Significance & ** & $*$ & $*$ & $* *$ \\
\hline LSD (0.05) & 0.23 & 0.97 & 0.019 & 6.41 \\
\hline \multicolumn{5}{|l|}{ Variety (V) } \\
\hline TGx1448-2E & $2.21^{\mathrm{a}}$ & $0.94^{\mathrm{a}}$ & $0.021^{\mathrm{a}}$ & $46^{\mathrm{b}}$ \\
\hline TGx1955-10E & $2.21^{\mathrm{a}}$ & $0.92^{\mathrm{a}}$ & $0.013^{\mathrm{a}}$ & $41^{\mathrm{c}}$ \\
\hline TGx1835-10E & $1.99^{\mathrm{b}}$ & $1.36^{\mathrm{a}}$ & $0.019^{\mathrm{a}}$ & $57^{\mathrm{a}}$ \\
\hline Significance & $*$ & NS & NS & $* *$ \\
\hline LSD (0.05) & 0.11 & 0.48 & 0.009 & 3.21 \\
\hline \multicolumn{5}{|l|}{ Interaction } \\
\hline$\overline{I * V}$ & $* *$ & NS & $*$ & $*$ \\
\hline
\end{tabular}

\subsection{Effect of Interaction Between $\mathrm{N}$-source and Variety on Shoot Biomass (g plant $\left.{ }^{-1}\right)$}

Table 2 shows the interactive effect between $\mathrm{N}$-source and variety on shoot biomass. The highest shoot biomass was observed when TGx1955-10E was treated with urea followed by the shoot biomass of TGx1448-2E and TGx1835-10E in that arrangement. Averagely, Bg3 produced the highest shoot biomass regardless of the variety. TGx1955-10E accumulated the highest shoot biomass when inoculated with Sg4, Gw5, Gw3-2 and Am2 isolates. TGx1448-2E on the other hand accumulated highest shoot biomass when inoculated with Bg1-4, Am6-3, Kr5-5 and Sg6-3 isolates respectively while TGx1835-10E recorded highest shoot biomass only when inoculated with Sk2-3 isolate. 
Symbiotic Effectiveness of Rhizobia Strains Isolated from Nigerian Savanna

Table 2: Interaction between inoculation and soybean varieties on shoot biomass

\begin{tabular}{|l|c|c|c|}
\hline & TGx1448-2E & TGx1955-10E & TGx1835-10E \\
\hline N-sources & & & $1.52^{\text {l }}$ \\
\hline Control & $1.99^{\text {fghijk }}$ & $4.18^{\text {a }}$ & $2.86^{\text {c }}$ \\
\hline Urea & $3.78^{\text {b }}$ & $2.07^{\text {fghij }}$ & $1.79^{\text {hijkl }}$ \\
\hline Sg4 & $2.03^{\text {fghijk }}$ & $1.78^{\text {ijkl }}$ & $1.67^{\mathrm{kl}}$ \\
\hline Sg6-3 & $2.18^{\text {efgh }}$ & $2.22^{\text {defg }}$ & $1.98^{\text {fghijk }}$ \\
\hline Gw5 & $2.01^{\text {fghijk }}$ & $2.06^{\text {fghijk }}$ & $1.88^{\text {ghijkl }}$ \\
\hline Gw3-2 & $2.05^{\text {fghijk }}$ & $1.90^{\text {ghijkl }}$ & $2.12^{\text {fghi }}$ \\
\hline Sk2-3 & $2.08^{\text {fghij }}$ & $2.55^{\text {cde }}$ & $2.57^{\text {cd }}$ \\
\hline Bg3 & $1.94^{\text {ghijk }}$ & $2.07^{\text {fghij }}$ & $2.21^{\text {defg }}$ \\
\hline Bg1-4 & $2.34^{\text {def }}$ & $2.03^{\text {fghijk }}$ & $1.88^{\text {ghijkl }}$ \\
\hline Am2 & $1.99^{\text {fghijk }}$ & $1.95^{\text {fghijk }}$ & $1.71^{\text {ijkl }}$ \\
\hline Am6-3 & $2.07^{\text {fghij }}$ & $2.04^{\text {fghijk }}$ & $1.74^{\text {ijkl }}$ \\
\hline Kr5-5 & $2.04^{\text {fghijk }}$ & & \\
\hline SE & 0.139 & Means with different letter (s) indicated in the columns are significantly different $(\mathrm{p}<0.05)$. \\
\hline
\end{tabular}

\subsection{Effect of Interaction Between N-sources and Variety on Nodule Weight (g plant $\left.{ }^{-1}\right)$ of TGx Soybean Varieties}

The interaction between $\mathrm{N}$-sources (inoculation) and soybean variety is shown in Table 3 . The highest nodule weight of $0.078 \mathrm{~g} /$ plant was observed in TGx1448-2E when inoculated with isolate Sg4. TGx195510E and TG1835-10E however produced nodule weight of $0.016 \mathrm{~g}$ and $0.019 \mathrm{~g} \mathrm{plant}^{-1}$ respectively when inoculated with isolate Sg4. Isolate Am2 of Sudan savanna origin did not nodulate with TGx1448-2E and TGx1955-10E but nodulated with TGx1835-10E. Isolate Gw5 produced heavier nodules on TGx183510E than TGx1955-10E and TGx1448-2E respectively. Nodules produced on TGx1835-10E by isolate $\mathrm{Bg} 3$ was heavier than nodules produced on TGx1448-2E and TGx1955-10E in that order. This trend was also observed when these varieties were inoculated with isolate Gw3-2. Isolate Sk2-3 produced heavier nodules TGx1955-10E and lighter nodules on TGx1448-2E (0.009 $\left.\mathrm{g} \mathrm{plant}^{-1}\right)$. This pattern was observed when these varieties were inoculated with isolate Bg1-4. Isolate Am6-3 produced heavier nodules on TGx1955-10E than TGx1448-2E and TGx1835-10E respectively. Nodules produced on TGx1448-2E by isolates Kr5-5 and Sg6-3 was heavier than nodules produced on TGx1835-10E and TGx1955-10E in that order.

\subsection{Effect of Interaction Between N-source and Variety on Percentage Symbiotic Effectiveness of Rhizobia Isolate}

The interactive effect between $\mathrm{N}$-source and variety on percentage symbiotic effectiveness (SE) is shown in Table 4. The highest SE of $90 \%$ was observed when TGx1835-10E was inoculated with Bg3 isolate while the lowest SE (42\%) was observed when TGx1955-10E was inoculated with Sg6-3 isolate. TGx1835$10 \mathrm{E}$ recorded the highest $\mathrm{SE}$ value when inoculated with all the isolates. With the exception of Bg3, inoculation with the isolates produced SE values with TGx1448-2E next to the values recorded by TGx1835-10E. 
Bolarinwa et al., Adv. J. Grad. Res.; Vol. 5, Issue 1, pp: 24-32, January 2019

Table 3: Interaction between inoculation and soybean varieties on nodule dry weight

\begin{tabular}{|l|c|c|c|}
\hline & \multicolumn{2}{|c|}{ Variety } \\
\hline N-sources & & TGx1955-10E & TGx1835-10E \\
\hline Control & $0.000^{\mathrm{g}}$ & $0.000^{\mathrm{g}}$ & $0.000^{\mathrm{g}}$ \\
\hline Urea & $0.000^{\mathrm{g}}$ & $0.000^{\mathrm{g}}$ & $0.000^{\mathrm{g}}$ \\
\hline Sg4 & $0.078^{\mathrm{a}}$ & $0.016^{\text {efg }}$ & $0.019^{\text {cdefg }}$ \\
\hline Sg6-3 & $0.028^{\text {bcdefg }}$ & $0.003^{\text {fg }}$ & $0.005^{\text {fg }}$ \\
\hline Gw5 & $0.014^{\text {efg }}$ & $0.024^{\text {cdefg }}$ & $0.051^{\text {abc }}$ \\
\hline Gw3-2 & $0.015^{\text {efg }}$ & $0.010^{\text {fg }}$ & $0.022^{\text {cdefg }}$ \\
\hline Sk2-3 & $0.009^{\text {fg }}$ & $0.035^{\text {bcdef }}$ & $0.057^{\text {ab }}$ \\
\hline Bg3 & $0.049^{\text {abcd }}$ & $0.016^{\text {ffg }}$ & $0.017^{\text {efg }}$ \\
\hline Bg1-4 & $0.005^{\text {fg }}$ & $0.026^{\text {bcdefg }}$ & $0.017^{\text {efg }}$ \\
\hline Am2 & $0.000^{\mathrm{g}}$ & $0.000^{\mathrm{g}}$ & $0.008^{\text {fg }}$ \\
\hline Am6-3 & $0.010^{\text {fg }}$ & $0.020^{\text {cdefg }}$ & $0.018^{\text {defg }}$ \\
\hline Kr5-5 & $0.046^{\text {abcde }}$ & $0.001^{\text {g }}$ & \\
\hline SE \pm & 0.012 & & \\
\hline
\end{tabular}

Table 4: Interaction between inoculation and soybean varieties on percentage symbiotic effectiveness

\begin{tabular}{|c|c|c|c|}
\hline & \multicolumn{3}{|c|}{ Variety } \\
\hline & TGx1448-2E & TGx1955-10E & TGx1835-10E \\
\hline \multicolumn{4}{|c|}{ N-sources } \\
\hline Control & $0^{\mathrm{m}}$ & $0^{\mathrm{m}}$ & $0^{\mathrm{m}}$ \\
\hline Urea & $0^{\mathrm{m}}$ & $0^{\mathrm{m}}$ & $0^{\mathrm{m}}$ \\
\hline $\mathrm{Sg} 4$ & $54^{\text {fghijk }}$ & $49^{\text {hijkl }}$ & $63^{\mathrm{def}}$ \\
\hline Sg6-3 & $57^{\text {efghij }}$ & $42^{1}$ & $58^{\text {defghi }}$ \\
\hline Gw5 & $53^{\text {fghijkl }}$ & $53^{\text {fghijkl }}$ & $69^{\mathrm{bcd}}$ \\
\hline Gw3-2 & $54^{\text {fghijk }}$ & $49^{\text {hijkl }}$ & $66^{\text {cde }}$ \\
\hline Sk2-3 & $55^{\text {efghijk }}$ & $45^{\mathrm{kl}}$ & $74^{\mathrm{bc}}$ \\
\hline $\mathrm{Bg} 3$ & $51^{\text {ghijkl }}$ & $61^{\text {defg }}$ & $90^{\mathrm{a}}$ \\
\hline Bg1-4 & $62^{\text {defg }}$ & $49^{\text {hijkl }}$ & $78^{b}$ \\
\hline $\mathrm{Am} 2$ & $53^{\text {fghijkl }}$ & $48^{\mathrm{ijkl}}$ & $66^{\text {cde }}$ \\
\hline Am6-3 & $55^{\text {efghijk }}$ & $47^{\mathrm{jkl}}$ & $59^{\text {defgh }}$ \\
\hline Kr5-5 & $54^{\text {fghijk }}$ & $49^{\text {hijkl }}$ & $61^{\text {defg }}$ \\
\hline $\mathrm{SE} \pm$ & 3.94 & & \\
\hline
\end{tabular}

Means with different letter (s) indicated in the columns are significantly different $(\mathrm{p}<0.05)$. 


\section{Conclusion}

From the study, only isolate Am2 did not form nodules with TGx1448-2E and TGx1955-10E but nodulated on TGx1835-10E. Generally, with the exception of isolate $\mathrm{Bg} 3$ and $\mathrm{Bg} 1-4$, higher shoot biomass gain was observed with TGx1448-2E and TGx1955-10E when inoculated with the isolates, but a lower shoot biomass gain was observed with TGx1835-10E upon inoculation with the isolates. Therefore, there was variation in the percentage symbiotic effectiveness of the rhizobia strains associating with these varieties.

\section{How to Cite this Article:}

S. Bolarinwa and A. Uzoma, "Symbiotic Effectiveness of Rhizobia Strains Isolated from Nigerian Savanna", Adv. J. Grad. Res., vol. 5, no. 1, pp. 24-32, Oct. 2018. doi: 10.21467/ajgr.5.1.24-32

\section{References}

[1] G.E.D. Oldroyd, "Speak, friend, and enter: signalling systems that promote beneficial symbiotic associations in plants," Nature Reviews Microbiology, vol. 11, pp. 252-263, (2013).

[2] E.M. Lodwig, A.H. Hosie, A. Bourdès, K. Findlay, D. Allaway, R. Karunakaran, J. Downie and P.S Poole, "Aminoacid cycling drives nitrogen fixation in the legume-Rhizobium symbiosis," Nature, vol. 422, no. 6933, pp. 722-726, (2003).

[3] J.A. Downie, "The roles of extracellular proteins, polysaccharides and signals in the interactions of rhizobia with legume roots," FEMS Microbiology Review, vol. 34, pp. 150-170, (2010).

[4] D.J. Gage, "Infection and invasion of roots by symbiotic, nitrogen-fixing rhizobia during nodulation of temperate legumes," Microbiology and Molecular Biology Review, vol. 68, no. 2, pp. 280-300, June 2004.

[5] H. Sawada, L.D. Kuykendall and J.M. Young, "Changing concepts in the systematics of bacterial nitrogen-fixing legume symbionts," Journal of General and Applied Microbiology, vol. 49, pp. 155-179. (2003).

[6] Q. Cheng, "Perspectives in biological nitrogen fixation research," Journal of Integrated Plant Biology, vol. 50, pp. 786-798, (2008).

[7] N.A. Moran, "Symbiosis as an adaptive process and source of phenotypic complexity," Proceedings of the National Academy of Sciences USA vol. 104, no. 1, pp. 8627-8633, June 2007.

[8] P.M. Vitousek, D.N.L. Menge, S.C. Reed and C.C. Cleveland, "Biological nitrogen fixation: rates, patterns and ecological controls in terrestrial ecosystems," Philosophical Transactions of the Royal Society of London. Series B: Biological Sciences, vol. 368, no. 1621, pp. 20130119, July 2013.

[9] J.B. Joy, "Symbiosis catalyses niche expansion and diversification," Proceedings of Biological Sciences, vol. 280, no. 1756, pp. 20122820, February 2013.

[10] A.A. Agrawal and M.G. Weber, "Defense mutualisms enhance plant diversification," Proceedings of the National Academy of Sciences USA vol. 111, no. 46, pp. 16442-16447, October 2014.

[11] J.L. Bronstein, "Our current understanding of mutualism," Quarterly Review of Biology, vol. 69, no. 1, pp. 31-51, March 1994.

[12] M. McFall-Ngai, M.G. Hadfield, T.C.G. Bosch, H.V. Carey, T. Domazet-Loso, A.E. Douglas, ....... J. Wernegreen, "Animals in a Bacterial World, a New Imperative for the Life Sciences," Proceedings of the National Academy of Sciences, vol. 110, no. 9, pp. 3229-3236, (2013).

[13] D.K. Aanen, H.H. De Fine Licht, A.J.M. Debets, N.A.G. Kerstes, R.F. Hoekstra and J.J. Boomsma, "High Symbiont Relatedness Stabilizes Mutualistic Cooperation in Fungus-Growing Termites," Science, vol. 326, no. 5956, pp. 1103 - 1106, November 2009.

[14] E.T. Kiers, M. Duhamel, Y. Beesetty, J.A. Mensah, O. Franken, E. Verbruggen, ... H. Bücking, "Reciprocal rewards stabilize cooperation in the mycorrhizal symbiosis" Science Magazine, vol. 333, no. 6044, pp. 880-882, June, 2011.

[15] M. McFall-Ngai, "Divining the essence of symbiosis: Insights from the squid-vibrio model," PLOS Biology, vol. 12, no. 2, pp. 1001783, February 2014.

[16] M. Albareda, D.N. Rodriguez-Navarro and F.J. Temprano, "Innoculation: dose, N-fertilizer supplementation and rhizobial persistence in soil," Field Crops Research, vol. 113, pp. 352-356, September 2009.

[17] FAO, (2014). FAOSTAT. Rome, http://faostat3.fao.org/home

[18] H. Tefera, "Breeding for promiscuous soybeans at IITA. In: Sudaric, A. (Ed.), Soybean-Molecular Aspects of Breeding. Intech, Rijeka, Croatia,” April 2011.

[19] K. Jensen, D. Mayntz, S. Toft, F.J. Clissold, J. Hunt, D. Raubenheimer and S.J. Simpson, "Optimal foraging for specific nutrients in predatory beetles," Proceedings of the Royal Society of London B: Biological Sciences, vol. 279, pp. 2212-2218, January 2012.

[20] S.R. Alexandra, P.X. Rogerio, C.O. Octavia, U.B. Segundo, J.A. Bruno and M.B. Robert, "Long-term effects of pre-harvest burning and nitrogen and vinasse applications on yield of sugar cane and soil carbon and nitrogen Stocks on a plantation in pernambuco, N.E.Brazil," Plant and Soil, vol. 281, pp. 339-351, March, 2006.

[21] G.N. Chemining'wa and J.K. Vessey, "The abundance and efficacy of Rhizobium leguminosarum bv.viciae in cultivated soils in eastern Canadian prairie," Soil Biology and Biochemistry, vol. 38, pp. 294-302, February, 2006.

[22] M. Hungria and M.A. Vargas, "Environmental factors affecting N2 fixation in gratn legumes in the tropics, with an emphasis on Brazil," Field Crops Research, vol. 65, pp. 151-164, January 2000.

[23] R.C. Abaidoo, H.H. Keyser, P.W. Singleton, K.E. Dashiell and N. Sanginga, "Population size, distribution, and symbiotic characteristics of indigenous Bradyrhizobium spp. that nodulate TGx soybean genotypes in Africa," Applied Soil Ecology, vol. 35, pp. 57-67, January 2007.

[24] N.Z. Lupwayi, G.W. Clayton, K.G. Hanson, W.A. Rice and V.O. Biederbeck, "Endophytic rhizobia in barley, wheat and canola roots," Canadian Journal of Plant Science, vol. 84, pp. 37-45, January 2004. 
[25] A. Javaid and N. Mahmood, "Growth, nodulation and yield response of soybean to biofertilizers and organic manures," Pakistan Journal of Botany, vol. 42, pp. 863-871, December 2010.

[26] J.C. Biswas, J.K. Ladha and F.B. Dazzo, "Rhizobia inoculation improves nutrient uptake and growth of lowland rice," Soil Science Society of America Journal, vol. 64, pp. 1644-1650, September, 2000.

[27] A.G. Ojanuga, "Agroecological Zones of Nigeria Manual.FAO/NSPFS, Federal Ministry of Agriculture and Rural Development, Abuja, Nigeria, 124 pp, 2006

[28] SAS Institute, Inc. 2008. Using JMP 10. SAS Institute, Inc., Cary, NC

Publish your research article in AIJR journals-

$\checkmark \quad$ Online Submission and Tracking

$\checkmark$ Peer-Reviewed

$\checkmark$ Rapid decision

$\checkmark \quad$ Immediate Publication after acceptance

$\checkmark \quad$ Articles freely available online

$\checkmark \quad$ Retain full copyright of your article.

Submit your article at journals.aijr.in
Publish your books with AIJR publisher-

$\checkmark \quad$ Publish with ISBN and DOI.

$\checkmark \quad$ Publish Thesis/Dissertation as Monograph.

$\checkmark \quad$ Publish Book Monograph.

$\checkmark \quad$ Publish Edited Volume/ Book.

$\checkmark \quad$ Publish Conference Proceedings

$\checkmark \quad$ Retain full copyright of your books.

Submit your manuscript at books.aijr.org 